\title{
A comparison of nearby incremental ground level and in plant concentrations of air pollutants emitted from electronics facilities
}

\author{
"P. L. Law, S. C. Gracie Chong, A. Baharun and A. Abdul Rahman
}

Department of Engineering, University of Malaysia Sarawak (UNIMAS), Kota Samarahan, Sarawak, Malaysia

Received 22 March 2006; revised 25 May 2006; accepted 5 June 2006; available online 25 June 2006

\begin{abstract}
Air dispersion modeling by was recently conducted to predict the incremental ground level and inplant concentrations of toxic organic chemicals due to stack and fugitive emissions from Sama Jaya Free Industrial Zone (SJFIZ), Kuching, Sarawak, Malaysia. Simulations of organic air pollutants emitted from industrial facilities in SJFIZ from years 1996 to 2001 were carried out in September 2004 by members of Faculty of Engineering, Universiti Malaysia Sarawak (UNIMAS). The results indicated that there were negligible amount of maximum incremental ground level concentrations of less than $3 \times 10^{-2} \mu \mathrm{g} / \mathrm{m}^{3}$ for 365 -day average, and less than $18 \times 10^{-2} \mu \mathrm{g} / \mathrm{m}^{3}$ for $24 \mathrm{~h}$. average. For in-plant maximum incremental concentrations, it is found that the simulated results were much lower than TWA values, except xylene. The predicted in plant concentration of xylene was 119.21 (parts per million) ppm as compared to ACGIH TLV-TWA of $100 \mathrm{ppm}$ approximately $19 \%$ higher than ACGIH recommended values. From this study, it was concluded that both nearby population and in plant workers were not potentially at risk to exposing organic chemicals far lower than the threshold limit levels set by ACGIH.
\end{abstract}

Key words: Incremental, ground level, in plant, air pollutants, emission

\section{INTRODUCTION}

The Sama Jaya Free Industrial Zone (SJFIZ) is located at Muara Tabuan, Kuching, Sarawak, Malaysia (01'28’33.3"N, 110¹9’28.2"E) which will be developed exclusively by electronics, electrical and other related industries (MID, 1996 and 2001). The area of this industrial zone, which is by Sungai Kuap, is approximately 330.5 hectares (MID, 1996 and 2001). As shown in Fig. 1, the SJFIZ is approximately $6 \mathrm{~km}$ away from the centre of Majlis Bandaraya Kuching Selatan (MBKS) or City of Kuching (MID, 1996). Nine approved industrial facilities have been established in SJFIZ until now. The nearest residential area at Muara Tabuan is less than one kilometre away from the industrial zone and the health risk impacts are expected to be present due to the magnitude of the production (MID, 1996). However, the air pollutants emitted from the industrial facilities could be hazardous to the nearby population and in plant workers (Gracie Chong, 2004). Most of the industrial wastes generated from SJFIZ are in solid, semi-solid and liquid forms, e.g., solvent, oil, sludge, liquid and solids wastes (Gracie Chong, 2004). However, most of the solvents and liquids are volatile, like the organic degreasing solvent (methylene chloride,

*Corresponding author, Email: puonglaw@feng.unimas.my

Tel.: +6082-672 317; Fax: +6082-672 317 perchloroethylene, trichloroethylene, 1, 1, 1trichloroethane and trichlorotri-fluoroethane) (MID, 2001 and Gracie Chong, 2004). Based on the data supplied by electronics facility operators located in SJFIZ, it was estimated that about $20 \%$ of the volatile solvents and $5 \%$ of liquids were evaporated and emitted into the atmosphere during operation as indicated by the differences between the amount solvents/liquids purchased and disposed off as liquid wastes (Gracie Chong, 2004). Based on the program and developed area, the assumed quantity of chemical used in process line from the SJFIZ is shown in Table 1 (MID, 2001). The monthly waste total emissions from the industrial facilities in SJFIZ are shown in Table 1, and the primary organic degreasing solvents air emissions from SJFIZ are ammonia, ethylbenzene, ethylene glycol, methanol, methyl ethyl ketone, toluene, trichloroethylene and xylene (Gracie Chong, 2004). The estimated total air emissions SJFIZ industries are presented in Table 1, and estimated emission rates by engineering calculation methods for major chemicals are shown in Table 2 (Gracie Chong, 2004). However, most of the solvents and liquids are volatile, such as the organic degreasing solvents such as methyl ethyl ketone, toluene, xylene and methanol (MID, 1996). The estimated total 